\title{
Demokrasi ve Türk Demokratikleşmesi Bağlamında Cumhurbaşkanlığı Hükümet Sistemi
}

\author{
Gökmen KANTAR \\ Tekirdağ Namık Kemal Üniversitesi, İktisadi ve İdari Bilimler Fakültesi, Siyaset Bilimi ve Kamu Yönetimi \\ gkantar@nku.edu.tr \\ ORCID ID: https://orcid.org/ 0000-0001-5120-110X
}

Derleme Makalesi

DOI: $10.31592 /$ aeusbed.664875

Gelis Tarihi: 25.12.2019

Revize Tarihi: 25.02 .2020

Kabul Tarihi: 26.02 .2020

\section{Atıf Bilgisi}

Kantar, G. (2020). Demokrasi ve Türk demokratikleşmesi bağlamında Cumhurbaşkanlığı Hükümet Sistemi. Ahi Evran Üniversitesi Sosyal Bilimler Enstitüsü Dergisi, 6(1), 123-135.

\section{ÖZ}

Osmanlı Devleti'nin son döneminde başlayan modernleşme hareketleri, Türk demokrasinin temel yapısını olușturur. Birinci Dünya savaşı sonunda yıkılmaya yüz tutmuş, işgal altındaki Osmanlı Devleti içerisinden; Türk Kurtuluş mücadelesi neticesinde Ankara merkezli modern bir millî devlet ortaya çıktı. Türkiye'de 1923'te Cumhuriyetin ilanı ile belirginleşen bu siyasi gelişmeler, Türk demokrasisinin ana omurgasını ve ilk dönemini oluşturur. II. Dünya savaşı sonrası "Batı demokrasisi" diktatörlüklere ve tek parti yönetimlerine karşı zafer kazanmıştır. Türkiye, 1945 yılında hem dış gelişmelere hem de iç gelişmelere bağlı olan dinamik bir siyasal dönüşüm sürecine girmiştir. 1946 yılında Türkiye'de Demokrat Parti'nin kurulması ile Türk siyasi hayatında kurucu dönem bitmiş; ikinci dönem başlamıştır. Bu tarihten itibaren demokrasisini süreklilik ve kalıcılık açısından güçlendirmeyi hedefleyen Türkiye, parlamenter sistem ile yoluna devam etmiştir. 16 Nisan 2017 Anayasa Referandumu ile yönetimde yöntem değişikliğine giden Türkiye, Cumhurbaşkanlığı Hükümet Sistemine geçti. Bu çalışmada modern demokrasi kavramı ve Türk Siyasi Tarihi içerisindeki rolü üzerinde durulacaktır. Ayrıca Cumhurbaşkanlığı Hükümet sisteminin, demokrasinin gelişimine ne gibi katkılar sağladığı, değerlendirilecektir.

Anahtar Kelimeler: Demokrasi, cumhuriyet, Türk demokrasisi, Türk siyasi hayatı.

\section{In The Context of Democracy and Turkish Democratızatıon; Presıdential Government System}

\begin{abstract}
Modernization movements starting in the last period of the Ottoman Empire constitute the basic structure of Turkish democracy. At the end of the first World War, a modern national state based in Ankara emerged as a result of the struggle for Turkish independence from within the occupied Ottoman state. These political developments, which became evident in Turkey in 1923 with the proclamation of the Republic, constitute the main backbone of Turkish democracy and its first period. II. After World War, "Western democracy" triumphed over dictatorships and one-party administrations. In 1945, Turkey entered a dynamic process of political transformation that depends on both foreign and domestic developments. With the establishment of the Democratic Party in Turkey in 1946, the founding of the first term of the Turkish political life was finished; the second term began. Since then, Turkey has continued its path with the parliamentary system, which aims to strengthen its democracy in terms of continuity and permanence. With the referendum of 16 April 2017, Turkey shifted to the Presidential government system. In this study, the role of the Republic of Turkey in the political history of democracy and Turkish political history will be emphasized. It will also be evaluated how the presidential government system contributes to the development of democracy.
\end{abstract}

Keywords: Democracy, republic, Turkish democracy, Turkish political life.

\section{Giriş}

Demokrasi kavramı, günümüzde sık kullanılan ve farklı anlamlar yüklenilen bir kavramdır. Demokrasi kavramının, ortaya çıktığı dönemden bugüne kadar birçok tanımlaması yapılmıştır. $\mathrm{Bu}$ tartışmalar demokrasinin, gerçek tanımının ne olduğu noktasında devam etmektedir. Bu anlam karmaşasının nedeni, her toplumun kendine ait siyasal, sosyal ve ekonomik farklılığı ile açıklanabilir. Kuramsal olarak demokrasi, günümüzdeki şekliyle 18. Yüzyılda ortaya çıkmış ve bütün Dünyay1 etkilemiştir. Modernizm gelişmesine dayalı olan demokrasi kavramı, bireyi esas alan ve eşit yurttaşlık ilkesine göre egemenliği tanımlayan bir düşüncedir. Tarihsel süreçte Türk toplumu, günümüze kadar demokrasiyi benimsemiş ve demokratikleşme yönünde atılan adımları desteklemiștir. Osmanlı Devletinde Tanzimat Fermanı'nın (1839) ilanı, Türk Demokrasisinin belirleyici temeli olmakla 
beraber; siyasi katılımın ve kurumsal yapıların oluştuğu bir dönüm noktasıdır. Birinci Dünya savaş1 sonunda mağlup olan Osmanlı Devleti içerisinden; Türk Kurtuluş mücadelesi neticesinde Ankara merkezli modern bir millî devlet ortaya çıkmıştır. 23 Nisan 1920'de Milli Egemenliğe dayalı Türkiye Büyük Millet Meclisi'nin (TBMM) açılması ve 29 Ekim 1923'te Cumhuriyetin ilanı ile birlikte yeni kurulan Türkiye Cumhuriyeti Devleti'nin yönetim şekli belirlenmiştir. TBMM içerisinde oluşan partileşme süreci ile birlikte Türk demokrasisinin ilk dönemi ve kurumsallaşması sağlanmıştır. 1946 yılında Türkiye'de Demokrat Parti'nin kurulması ile Türk siyasi hayatında kurucu ilk dönem bitmiş; ikinci dönem başlamıştır. Bu tarihten itibaren demokrasisini süreklilik ve kalıcılık açısından güçlendirmeyi hedefleyen Türkiye, parlamenter sistem ile yoluna devam etmiştir. 16 Nisan 2017 Anayasa Referandumu ile yönetimde yöntem değişikliğine giden Türkiye, "Cumhurbaşkanlığı Hükümet Sistemi ”ne geçerek, demokrasisini her açıdan güçlendirmeyi amaçlamıştır.

$\mathrm{Bu}$ çalışmada ilk olarak modern demokrasi kavramı ve Türk Siyasi Tarihi içerisindeki demokratikleşme hareketleri üzerinde durulacaktır. İkinci olarak çalışma içerisinde 1920-1945 yılları arasında Cumhuriyetin İlanı ve demokrasinin kurumsallaşma süreci incelenecektir. Üçüncü olarak çalışmada Türkiye'de çok partili demokratik hayata geçiş ve parlamenter sistemin genel durumu değerlendirilecektir (1946-2017). Dördüncü olarak çalışma içerisinde demokraside yöntem tartışmaları ve Cumhurbaşkanlığı Hükümet sistemi üzerinde durulacaktır. Nitel bir araştırma olarak yapılan çalışmanın odak noktası demokrasi ve Türkiye'de demokratikleşme sürecidir. Sonuç olarak ortaya çıkan bilgilerin, Türk demokratikleşmesi bağlamında Cumhurbaşkanlığı Hükümet sistemine ve Türk demokrasine ne gibi katkılar sağladığı, değerlendirilecektir.

\section{Modernizm ve Osmanlı Dönemi Demokratikleşme Hareketleri}

Modernite, toplumsal ve siyasal yaşam alanlarının tümünde değişimin yaşanması, toplumun geleneksel değerlerinden soyutlanarak; yeniden tasarlanması anlamına gelmektedir. Modernite, modern düşüncenin tüm dünyaya yayılmasıyla oluşan bir toplumsal değerler sistemi olarak ifade edilmiştir. Modernizm düşüncesi, aydınlanma felsefesine göre ideal toplum düzeni olarak tanımlanmıştır. Çünkü modernizm eleştirel düşünce demektir. Birey, eleştiri ve akıl kavramları üzerine kuruludur. Akılcı, ilerlemeci, olgusal bir bakış açısı taşır. Evrensel ilkelere dayalı bir bakış açısına sahiptir. Modernizm, genel olarak 19. yüzylldan başlayarak; 20. yüzyllın belli bir dönemine kadar toplumsal alanı her konuda tesiri altına aldığı bir olgu olarak kabul edilmektedir (Marshall, 1999).

Genel olarak Batı ile olan ilişkisi açısından Osmanlı Devleti, 19. yüzyılda Avrupa'daki modernleşme çabalarını dikkatle takip etmiştir (Mardin, 1994). Ancak Osmanlı modernleşme süreci, Batı modernleşmesi ile benzer özellikler göstermez. Bunun nedeni Batı'da yenileşme süreçlerinin, devletin dışında toplumsal hareketler ile oluşmasıdır. Bu toplumsal düzenlemeler sosyal ve ekonomik alanda olduğu gibi kendisini siyasal olarak da hissettirmiştir. Batı'da modernleşme ile başlayan siyasal düşünce "halk egemenliğì" esaslı demokrasiyi ve demokratik kültürü yaygınlaştırmıştır. Osmanlı Devleti, toplumsal yapıyı dinsel olarak ayırmadan halkı, yönetici sınıf ve reaya olmak üzere ikiye ayırmıştır (Ubıcını, 2000). Osmanlı Devleti bu özelliği ile Batı'daki devletlerden farklı olarak bir sınıflandırma yoluna gitmiştir (Akyılmaz,1999). Bürokratik bir yapı olan Osmanlı Devleti, "mekezçevre" ilişkilerini temel alan bir yönetim anlayışına sahiptir. $\mathrm{Bu}$ sinıflandırma merkez olarak tanımlanan yönetici sınıf ile çevre olarak tanımlanan reaya (halk) arasında bir kopukluğa neden olmaktadır. Osmanlı yönetim sistemindeki patrimonyal düzen ve yönetim anlayışını ortaya koyan Şerif Mardin, yönetim ile halk arasında kopukluk olduğunu ifade etmektedir. Bu kopukluğun temel sebebini, iki yapıyı yakınlaştıracak ara bir yapının olmaması olarak açıklar. Batı'daki burjuvazinin varlığı bu iki yapı arasındaki gerilimi azaltmıştır. Osmanlı modernleşme hareketleri içerisinde bu yapı, tesis edilmeye çalışılmışsa da, geleneksel toplum yapısının aktörleri bu gelişmeyi engellemeye çalışmıştır (Mardin, 2003).

Osmanlı Devleti yönetim anlayışı özelliğini, Türk kültür ve değerlerinden almıştır. Bu nedenle devletle ile toplum arasındaki ilişki bir "sözleşme" veya "uzlaşma" yerine; devlet ve toplum arasındaki dengeli bir sınırlılık iktidarı söz konusudur. Çünkü Türk siyasi tarihini, devlet, egemenlik ve iktidar 
kavramları açısından incelediğimizde Avrupa'daki gelişmelerden farklılıklar gösterir. Türk devlet geleneğinde iktidarı ve güç kaynă̆ını belirleyen temel esas "Türk Töresi” dir. Türkler, İslamiyet'i benimsedikten sonra da bu egemenlik anlayışlarını, İslami bir metotla sistemleştirerek devam ettirmişlerdir. Kısaca özetlemek gerekirse Osmanlı Devleti'nde merkez-çevre ilişkileri merkezin, çevre üzerindeki iktidarına veya çevrenin merkeze olan mutlak itaatine dayanmamaktadır (Özdemir, 2009). Osmanlı Devleti'nde modernleşme hareketleri, Türk demokratikleşmesinin, söylem merkezini ve temel yapısını oluşturmaktadır. Bununla beraber, geleneksel yapıdan modern demokratik yapıya geçiş sürecini başlatmıştır. Osmanlı Devletinde Tanzimat Fermanı (1839) ilanı, günümüz Türk Demokrasisinin belirleyici temeli olmakla beraber; Siyasi katılımın ve siyasi kurumsal yapıların oluşmaya başladığı bir dönüm noktasıdır. Tanzimat öncesi var olan geleneksel yönetim ve bürokratik yapı daha çok padişaha danışma niteliğinde iken; Tanzimat sonrasında oluşturulan meclislerde, yönetimde temsili ve katılımı sağlamıştır. Tanzimat dönemi bu öznelliği ile Türk Siyasi Hayatında ciddi bir dönüşüm noktasıdır (Kalaycıoğlu ve Sarınay,1994). Türk demokrasisinin ilk kurumsal yapılarını meydana getiren Tanzimat Fermanı, yazılı ve evrensel hukuk kurallarının Osmanlı toplumsal hayatı içerisinde ortaya çıkmasına sebep olmuştur. Ayrıca Tanzimat, Osmanlı yönetiminde Meşrutiyete dayalıbir egemenlik ilişkisinin de zeminini hazırlamıştır. Tanzimat, içeriği ile aradan yıllar geçmesine rağmen Türk demokrasi sürecinin başlangıç noktası ve devamlılığını sağlayan itici gücüdür (Güngör, 1993).

Diğer taraftan Osmanlı Devleti'nde modernleşme hareketleri, orta sınıfin oluşmasına ve siyasi olarak güç kazanmasına sebep olmuştur. Bu adım devlet otoritesini, padişahın elinden alarak halkın oyuna bağlayan demokratik ilk adımdır (Karpat, 2012). Ancak bu süreç 1877-1878 Osmanl1-Rus Savaşının çıkması sebebiyle demokratik bir yapının kurulmasına ve işlemesine katkı sağlayamadan ertelenmiş; ilk Osmanlı Anayasası bu nedenle yürürlükten kaldırılmıştır. Daha sonra Meşrutiyetin, 1908 yılında yeniden ilan edilmesi ile kapalı olan meclis açılmış ve askıya alınan anayasa tekrar yürürlüğe girmiştir. Osmanlı Devleti'nde Meşrutiyet'in ikinci kez ilanı ile siyasi partiler kurulmuş ve seçimlere katılma hakkı kazanmışlardır. Bu yeni sistem ile demokratik ortam oluşturularak, ilk defa siyasi parti merkezli bir temsil ve katılım olgusu; Osmanlı Türk toplumunun siyasi gerçeği haline gelmiş̧ir. Bu süreç Türk demokrasisinin, merkezi ve çevresel aktörler arasında ilişkilerini düzenleyen bir belirleyici olurken; kurumsallaşmasına ve dönüşümüne katk1 sağlamıştır. Bu demokratik dönüşüm, Osmanlı Döneminden başlayarak; Cumhuriyet Döneminde kurumsallaşmasını tamamlamıştır. Sonuç olarak modernleşme kavramının ilke ve prensiplerinden yola çıkılarak yapılan demokratikleşme hareketleri; Osmanlı egemenlik anlayışını padişahın şahsından alarak, birey ve toplum lehine olacak şekilde yeniden düzenlemiştir.

\section{Türkiye’de Cumhuriyetin İlanı ve Demokrasinin Tesisi (1920-1945)}

Türk siyasi tarihinde demokrasinin gelişim süreci birçok kaynakta bölümlere ayrllarak incelenmiştir. Bundan önce incelediğimiz Osmanlı Devleti dönemi demokratikleşme hareketleri ilk dönem olmaktan çok Türk demokrasisinin, önsözü, odak noktas1 ve giriş bölümü olma niteliğindedir. Şimdi inceleyeceğimiz dönem Türk demokrasisi açısından yöntemin devamlılığı kadar; yönetim açısından da Cumhuriyet İlanı (1923) ile güçlendirilmiştir. Türk "Kurtuluş Mücadelesi” ile başlayan süreç Lozan sonrası, 1923'te Cumhuriyet'in ilanı ile yeni bir devletin, yeni yönetim anlayışı ile Dünya'ya kabul ettirildiği dönemdir. Bu döneme birçok siyasi, sosyal ve ekonomik değişiklik yirmi beş yıllık kısa bir sürede gerçekleştirilmiştir. Atatürk'ün 19 Mayıs 1919'da Samsun'a çıkması ile başlayan kurtuluş mücadelesi işgal altındaki Türk milletini ümitlendirmiş ve mücadelenin ağırlık merkezini Anadolu olarak belirginleştirmiştir (Atatürk'ün Söylev ve Demeçleri, 1989, ss.2-3). Bu merkez "Erzurum Kongresi" ile Anadolu Müdafa-i Hukuk Cemiyeti'ni tek çatı altında toplarken; "Sivas Kongresi" ile de ile Anadolu ve Rumeli Müdafa-i Hukuk Cemiyet'lerini birleştirmiştir (Dursunoğlu,1946, s.13). Bu Cemiyetler ile kurtuluş mücadelesi, Atatürk'ün başkanlığında kurumsal bir kimlik kazanırken; milli irade ve milli güç ile Türk Halkı tek egemen güç olarak vurgulanmıştır. Atatürk bu amacını bir adım daha ileri götürerek, 19 Mart 1920 tarihli bir genelge ile ülke genelinde seçimlerin yapılmasını istenmiştir. Yapılan seçimler neticesinde 23 Nisan 1920'de TBMM açıldı ve kurtuluş mücadelesinin siyasal teşkilatlanması sağlanmıştır (Armaoğlu,1987). 
Demokrasi ve demokratikleşme yolunda birinci meclis, sadece yasama yetkisi ile değil yürütme yetkisini de kendisinde toplamış ve Meclis Başkanı olarak Atatürk'ü seçmiştir. Bu meclisin görevi, kurtuluş mücadelesini yönetmek ve yeni kurulacak Türk Devletinin kuruluş felsefesini hazırlamaktır (Eroğlu,1990). Bunun için Türk Devletinin ilk ve geçici Anayasası (Teşkilat-1 Esasiye) 20 Ocak 1921'de yürürlüğe girmiştir. Bu Anayasa kendi meşruiyetini "hâkimiyet bilakayd-i milletindir" olarak ifade ederek; milli egemenlik düşüncesi ile hareket etmiştir (Öztekin,1993). TBMM, bu anayasa ile işlerlik kazanmış; iktidar (1.grup) ve muhalefet (2.grup) ikiliğine dayalı olarak çalışmıştır. Meclis hükümet sistemi olarak çalışan TBMM, bu anayasayla kurtuluş mücadelesini zaferle sonuçlandırmış, saltanatı kaldırmış, Lozan'1 imzalayarak yeni Türk Devletini kurmuş ve 29 Ekim 1923'te Cumhuriyeti ilan etmiştir (Şıvgın,199). Ayrıca 11 Eylül 1923'te Anadolu ve Rumeli Müdafa-i Hukuk Cemiyetinin dernek başkanı olarak Atatürk, meclisteki grubunu "Halk Fıkrası" na dönüştürerek; fırkanın amacını demokrasi, çağdaşlaşma ve hukuk devleti olarak belirlemiştir (Tuncay,1992). Böylelikle Atatürk'ün ifadesi; "demokrasi prensibinin en asrî ve en mantıkî tatbikini temin eden hükümet şekli, cumhuriyettir" diyerek demokrasinin tesisi için cumhuriyet yönetimine geçilmiştir (İnan, 2000). Atatürk, Medeni Bilgiler kitabında "demokrasi prensibi”ni halk devleti, halk yönetimi, halkın kendi kaderine hâkim olması anlamında, siyasî demokrasi ile aynı anlamda kullanmıştır. O’na göre "bugün, demokrasi fikri daima yükselen bir denizi andırmaktadır." 19. yüzyıldan itibaren "demokrasi fikri, mukavemet edilemez bir kuvvet ve cereyan" halini almıştır (İnan, 2000).

Cumhuriyetin ilanı ile birlikte gündeme gelen hilafet meselesi, 3 Mart 1924'te TBMM genel kurulunda yasalaşarak kaldırılmıştır. Yine aynı yıl olağanüstü şartların dinamiği içerisinde yapılmış olan ilk anayasa (1921), mecliste değiştirilerek yeniden düzenlendi ve 20 Nisan 1924 yılında yeni bir anayasa olarak kabul edilmiştir. Bu anayasa milli egemenliği ve meclis üstünlüğü ile beraber; parlamenter sistemi tesis eden bir anayasadır. Meclis hükümeti sistemi yerine meclis içerisinden kurulan Bakanlar Kurulu ve Başbakan oluşan bir hükümet modelini getirmiştir (Öztekin,1993). Türkiye'nin ilk Başbakanı olan İsmet İnönü başkanlığındaki Cumhuriyet Halk Fırkası'na (CHF) karşı, mecliste muhalefet olarak Terakkiperver Cumhuriyet Firkası (TCF) 17 Kasım 1924'te kuruldu. Cumhuriyetin ilanından sonra parlamenter demokrasinin ilk denemesi olan TCF, Atatürk'ün de tavsiyesi dikkate alınarak; şeyh Sait olayı ile ilgili olduğu gerekçesiyle 3 Haziran 1925'te kapatılmıştır (Tuncay,1992). Daha sonra parlamenter demokrasinin ikinci denemesi olan Serbest Cumhuriyet Fırkası (SCF), Fethi Bey tarafından Atatürk'ün desteği ile 12 Ağustos 1930 kurulmuştur. Bu deneme parlamenter sistemin tesisi için demokratik bir denetleme çabasıydı. Böylece iktidar partisi olan CHF, mecliste muhalefet partisi tarafindan tam demokratik olmasa da denetlenebileceti (Ünal,1994). Fakat bu deneme üç ay sonra hem parti içi hem de CHF ile olan gerilimlerin ardından SCF, 17 Kasım 1930'da kapatılmıştır. Bu denemeden sonra Türkiye, demokrasisini tek parti yönetimi ile tesis etmede sıkıntılar yaşamıştır. Türkiye, siyasal ve toplumsal açıdan 1946 yılına kadar demokrasi açısından oldukça zor dönemler yaşamıştır. 10 Kasım 1938'de devletin kurucu önderi Atatürk'ün vefatı ile 11 Kasım 1938'de Cumhurbaşkanı olan İsmet İnönü, II. Dünya Savaşı'nı demokrasi bloğunun kazanmasından sonra; Türkiye'de çok partili demokratik sistemin önünü açmıştır (Ünal,199).

\section{Türkiye'de Çok Partili, Demokratik Hayat (1946-2017)}

Türkiye, 1945 yılında hem dış gelişmelere hem de iç gelişmelere bağlı olan dinamik bir siyasal dönüşüm sürecine girmiştir. Dış dünyada II. Dünya savaşı sonrası "Batı demokrasisi" diktatörlüklere ve tek parti yönetimlerine karşı zafer kazanmıştır. Diğer yandan ise iç kamuoyunda Cumhuriyet Halk Partisi'ne (CHP) karşı duyulan muhalefet, ülke genelinde kökleşerek yaygınlaşmıştır. Çok partili hayata geçiş sürecini ilk adımını 1945-46 yılları arasında başlatırsak; kesin geçişi demokratik seçimlerin yapıldığı ve iktidarın el değiştirdiği 1950 yılı ile sonuçlandırabiliriz (Kalaycıoğlu, 1989). Milli Şef İnönü, çok partili hayata geçiş sürecinde etkin bir rol oynamıştır. Bu süreçte ülkenin, iç ve dış şartlarını değerlendiren İnönü, siyasi tecrübeleri ile ön görülü davranarak Türkiye'de çok partili siyasi hayatın yolunu açmıştır. Celal Bayar, Adnan Menderes, Fuat Köprülü ve Refik Koraltan'dan oluşan "Dörtlü Takrir" grubu, parti içi muhalefet oluşturarak; demokratikleşme yönünde talepte bulundular. Daha sonra bu grup partiden kopma noktasına gelince, CHP'den ayrilarak 7 Ocak 1946'da Demokrat Parti'yi kurmuşlardır. İkinci Dünya savaşı sonunda iki kutuplu dünya 
düzeninin bir tarafında Amerika Birleşik Devletleri (ABD) ve Batı diğer tarafında ise Sovyet Sosyalist Cumhuriyeti Birliği (SSCB) yer almıştır. Türkiye, bu iki kutuplu yeni düzende Sovyet tehdidinin dışında ekonomik ve siyasi çıkarlarını gözeterek; ABD'nin başı çektiği liberal demokratik sistemi olmayı tercih etmiştir (Kürkçüoğlu,1979).

1947 yılında yapılacak genel seçimleri CHP, yeni kurulmuş parti olan Demokrat Parti’yi (DP) seçimlere hazırlıksız sokmak amacıyla erken seçim kararı almıştır. 21 Temmuz 1946' da CHP, DP ve Milli Kalkınma Partisi (MKP) katıldığı bu genel seçim; açık oy, gizli sayım kuralına göre yapılarak, adli denetleme yerine idari denetleme uygulanmıştır. Kamuoyunda sonuçlar bu sebeple tartış1sa da seçimlerde, CHP 395 ve DP ise 62 sandalye kazanmıştır. 1946 genel seçimleri, Türk siyaseti ve demokrasisi bakımından çok önemli bir kazanımdır. Çünkü TBMM'nin kuruluşundan bu tarihe kadar, mecliste seçilmiş muhalefet milletvekilleri hiçbir zaman yer almamıştır. DP'nin seçimlere katılıp meclis temsili kazanması ile Türk siyasetinde "muhalefet" demokratik meşruiyetini kazanmıştır. (Dursun, 1999). Türkiye, 14 Mayıs 1950 yılında yapılan demokratik seçimlerde CHP'nin tek parti iktidarına son vermiştir. Bu seçimler ülke genelinde demokratik kurallar neticesinde yapılmış olup; halkın iradesinin sandığa yansıtılmıştır. 14 Mayıs 1950 yılında yapılan seçimlerin sonuçlarına göre oyların \%53'nü DP alarak tek başına iktidar olmuştur (DİE,1995). Seçim ardından toplanan TBMM, Cumhurbaşkanı olarak Celal Bayar'ı seçerken; yeni hükümet Adnan Menderes'in Başbakanlığında kurulmuştur. $\mathrm{Bu}$ siyasal sonuçlar ile Türkiye, 1945 sonrası başlatmış olduğu toplumsal demokratikleşme sürecini tamamlamış olmuştur. 1950'den başlayan 10 yıllık DP iktidarı süreci, toplumsal alanda çok partili demokrasiye katkı sağlamış fakat siyasal alanda ise iktidar ve muhalefet arasında meşruluk zemininde gerilime sebep olmuştur. Türkiye 1946'da başlattığı demokratikleşme sürecini, siyasal kültürün gelişememesine bağlı olarak; askeri ve sivil seçkinlerin iktidar mücadelesi sonucunda 27 Mayıs 1960 askeri darbesiyle kesintiye uğratmıştır (Çavdar,1996). Türkiye'de toplumsal olarak darbe, bir kesimi mağdur ederken (DP kadro ve seçmenini); bir kesimi de memnun etmiştir. Bu memnun olan kesimin başında CHP kadroları vardı çünkü siyaseten seçimle iktidara gelmeleri pek mümkün görünmüyordu. Gazeteci Metin Toker'e göre 27 Mayıs Darbesi İnönü’nün bilgisi dışında meydana gelse deİnönü süreci siyasal krizin aşılmasında başka bir çare kalmadığını belirtmiştir (Toker, 1991). Yine diğer bir gazeteci ve politikacı olan İsmail Cem'e göre 27 Mayıs askeri darbesinin meydana gelmesinde bürokrasinin desteği söz konusu olup; bu dönemde CHP darbeyi destekleyen bir politika izlemiştir (Cem, 1998). Askeri darbeden sonra Türkiye, siyasal krizi aşmak ve demokratik düzene hızla geçmek için önemli adımlar atmıştır. Demokrasiye ara verilen bu süreçte, Turhan Feyzioğlu tarafından hazırlanan yeni anayasa 9 Temmuz 1961'de yapılan halk oylaması (\%61) ile kabul edilmiştir (Çavdar,1996). 1961 Anayasası, Cumhuriyet döneminde yapılan 1921 ve 1924 Anayasalarından farklı olarak; Batı demokrasisini ve siyasi katılımı temel almıştır. Böylece, Türk siyaseti yeniden demokratik çok partili hayata geçmiş ve devlet içinde demokrasinin kurumsallaşması sağlanmıştır. Bu anayasa ile birlikte yargıda Anayasa Mahkemesi kurulurken; TBMM: 450 üyeden oluşan Millet Meclisi ve 150 üyeden oluşan Senato Meclisinden meydana gelen ikili bir yaprya kavuşmuştur. 1961 Anayasasının kabulünden sonra 15 Ekim 1961'de yapılan seçimlerine dört parti katılmış ve CHP \%36,7 (173 Milletvekili) ile seçimi kazanan birinci parti olmuştur (DİE, 1998). Seçimlerden sonra Türkiye, diş politikaya önem vererek; 12 Eylül 1963’te Avrupa Ekonomik Topluluğuna (AET) üye olmuştur. CHP hükümeti tarafından imzalanan AET üyeliği, bu dönemde Türkiye'nin dış politikadaki en önemli siyasi ve ekonomik başarısıdır (Kürkçüoğlu,1979). Batı ile demokratik bağların devam ettiren bu Ankara Anlaşması (1963), Türkiye'yi dünya kamuoyunda rahatlatmış; bugün Avrupa ile olan ekonomik ve siyasi ilişkilerin temelini oluşturmuştur. CHP iktidarı 10 Ekim 1965'te yapılan seçimler ile sona ermiş, iktidara oyların \%52,9'unu alan Adalet Partisi (AP) gelmiştir. Bu sonuçlar ile birlikte AP, Türkiye'de iş başına gelirken; 12 Ekim 1969 seçimlerini de \%46,5 oy ile kazanarak iktidarını devam ettirmiştir (DİE,1998). Bu dönemde (1960-1970) Türk demokrasisi, toplumsal alana bağlı olarak hızlı bir dönüşüme girmiştir. Modernleşme ve sanayileşmenin etkisiyle başlayan bu dönüşüm, köyden kente göç ile önemli bir nitelik kazanmıştır. Seçmen davranışlarına yansıyan bu toplumsal hareketlilik, etnik, mezhepsel ve ideolojik farklılaşmayı da beraberinde getirmiştir.

1970'li y1llara Türkiye, siyasi, ekonomik ve toplumsal kutuplaşmalar ile girerken; Tük demokrasisi 12 Mart 1971'de yayınlanan askeri muhtıra ile tekrar tartışmalı hale gelmiştir 
(Ünal,1997). Askeri muhtıraya en ciddi tepki yurt dışından Avrupa Ekonomik Topluluğu'ndan (AET) gelmiş ve 1973 genel seçimlerinin zamanında yapılmasını sağlamıştır. Türkiye 14 Ekim 1973'te sandık başına $\% 66,8$ düşük bir katılım ile gitmiş ve seçimleri $\% 33,3$ oy ile Bülent Ecevit başkanlığındaki CHP kazanmıştır (DİE,1998). Seçimlerden sonra çıkan yönetim krizi iki yüz günlük bir aradan sonra kurulan CHP- Milli Selamet Partisi (MSP) koalisyon hükümeti ile aşılmıştır. Koalisyon hükümeti döneminde gerçekleşen Kıbrıs Barış Harekâtının, iç ve dış politikada ciddi yansımaları olurken; 1977 seçimleri de CHP'nin başarısı ile sonuçlanmıştır. Fakat 1977 seçimleri Türkiye'ye beklenen istikrarı getiremediği gibi ülkede ekonomik kriz, anarşi ve çatışma ortamında iç savaşın eşiğine gelmiştir (Hale,1996). Bu dönemde Türkiye, çift kutuplu dünya düzenine bağlı olarak; ideolojik, etnik ve mezhepsel farklılaşmayla çatışma ve anarşi ortamına girmiştir. Bu olaylar karşısında iktidarın ve muhalefetin siyaseten çözüm üretememesi, 12 Eylül 1980 askeri darbesine zemin hazırlamıştır. Türk Demokrasisi, 12 Eylül 1980'de askeri darbesi ile kesintiye uğrarken; demokrasi 1983'e kadar tamamen devre dışı bırakılmıştır. Ülke yönetimi darbeci askerler oluşturulan, Milli Güvenlik Konseyi tarafindan yürütülmüştür. Bu süreçte MGK, 1961 Anayasası yerine hukukçulara bireysel hak ve özgürlükleri kısıtlayıcı yeni bir anayasa hazırlatmıştır. Hazırlanan bu yeni Anayasa, 1982 yılında halkoylamasında \%92 oy ile kabul edildi ve daha sonra ise Kenan Evren Cumhurbaşkanı olmuştur (Çavdar,1996). Türkiye ara verilen demokrasiye, askeri vesayetin altında1983 seçimleriyle geçmiş fakat bu seçimler hem siyasi partilerin hem de milletvekili adaylarının karşılaştığı engellerin gölgesinde yapılmıştır. Seçimleri $\% 45,1$ oy alarak kazanan Anavatan Partisi (ANAP), Turgut Özal'ın Başbakanlığında yeni hükümeti kurmuştur. Askeri vesayetin gölgesinde devam eden Türk demokrasisi meşruluğunu, 6 Eylül 1987'de yapılan halk oylamasıyla (\%50,16 evet oyu) siyasi yasakları kaldırarak yeniden kazanmıştır (DİE, 1998). Türkiye'de demokratik sistem 12 Eylül'den sonra askeri vesayetin gölgesinde çok sağllklı işletilmemiştir. Koalisyon hükümetlerin etkin olduğu 1990'lı y1llar ekonomik, toplumsal ve siyasal alana yansıyan birçok sorunla karşılaşmıştır. Bu demokratik sorunlar, çözüm üretilemeden 2000'li yıllara taşınmıştır. Türkiye'nin bu dönem yaşadığ en büyük demokratik sorun seçim ile işbaşına gelen hükümetin 28 Şubat 1997 yılında MGK toplantısı ardından istifa etmesi olmuştur. Türk siyasetinde muhtıra olarak nitelenen 28 Şubat MGK kararları demokrasiyi yeniden tartışmalı hale getirmiştir. 28 Şubat süreci sonrası yapılan 18 Nisan 1999 seçimler yine koalisyonu işaret etmiş fakat üç buçuk yıl devam eden hükümet, 2001 ekonomik krizin sonrasında 3 Kasım 2002'de erken seçim kararı almıştır. Bu kararın sonrasında yapılan seçimlerde, TBMM'de bulunan siyasi partileri, seçim barajını aşamayarak mecliste temsil dışı kalmıştır. Seçmenin bu davranışı, Türk demokrasisi açısından özellikle sorumlu gördüğü siyasi yapıyı değiştirme kararı olarak algılandı ve baraj altında kalan birçok siyasi parti ve lideri siyaseten tasfiye olmuştur. 2002 seçimlerinde tek başına iktidara gelen Adalet ve Kalkınma Partisi (Ak Parti), 14 Ağustos 2001 yılında Recep Tayyip Erdoğan ve arkadaşları tarafindan kurulmuştur. Milli Görüş çizgisi geleneğine sahip kadro tarafından şekillenen Ak Parti, seçmen tarafından Türkiye'nin hem içinde bulunduğu ekonomik kriz hem de diş dünya ile olan ilişkilerinde umut olarak tercih edilmiştir. Türk demokrasinin önemli siyasi partilerinden olan Ak Parti, 2002 seçimlerinden sonra uygulamış olduğu ekonomik, toplumsal ve siyasal politikalar ile 2007, 2011, 2015 seçimlerinde, seçmenden tam not alarak yine tek başına iktidar olmuştur (Koç,2011). Türkiye'de demokratik siyaset, 15 Temmuz 2016 yılında, yeni bir darbe girişimi ile karşı karşıya kalmıştır. Bu darbe girişimine karşı Türk Milleti, demokrasiye olan inancı ve milli egemenliğe olan sadakati ile destansı bir direniş göstermiştir. Demokrasiye sahip çıkan bu milli direniş sayesinde darbe girişimi başarısızlıkla neticelenmiştir. Türk siyasi tarihine "15 Temmuz Destanı" olarak geçen bu milli direniş, demokrasi açısından önemli bir olaydır (Çakı,2018).

\section{Türkiye'de Demokraside Yöntem Değiş̧ikliği VE Cumhurbaşkanlığı Hükümet Sistemi}

Türkiye'de demokratik sistemin siyasal dönüşümü, Tanzimat'tan başlayarak günümüze kadar gelmiştir. Cumhuriyetin ilanı ile kuruluş felsefesinde yer alan modern, laik, demokratik ve hukuk devleti kavramları Türkiye Cumhuriyeti Devleti’nin var oluş ilkeleridir. Üniter devlet yapısına göre şekillenen devlet, 1923 yılından 1946 yılına kadar milli kimlik ve demokratik kurumsallaşmasını tesis etmeye çalışmıştır. Daha sonra 1946 ile başlayan çok partili hayat ve demokratik siyaset, demokratik olmayan yöntemlerin başında gelen darbeler ile engellenmiştir. Bu engelleyici vesayetçi anlayış, hem iç hem de dış politik ve ekonomik odaklardan beslense de darbelerin siyasette bu kadar etkili 
olmasının en temel nedeni; demokratik siyasal sistemin gücü ve gelişimi ile ilgilidir. Türk demokrasisinde, siyaset sisteminin gelişim sürecine yönelik tartışmalar, Cumhuriyetin kuruluşundan beri devam etmektedir. Bu tartışmaların aktöreleri değişse de odak noktasını, yönetimden ziyade yöntem tartışmaları olmasıdır.

\section{Türk Demokrasisinde Parlamenter Sistem ve Yöntem Tartışmaları}

$\mathrm{Bu}$ yöntem tartışmaları 1921 Anayasasının benimsediği kuvvetler birliği ilkesine karşı demokratik modeller üzerinde başlayarak; çok partili hayata geçtikten sonrada devam etmiştir. Bu tartışmalar 1970'lerdeki koalisyon hükümetleri döneminde yönetim zorluğu açısından daha farklı bir noktaya gelmiştir (Gülener,2016). Türk siyasetinde sağ partiler [MSP ve Millliyetçi Hareket Partisi (MHP)], bu tartı̧̧maları özellikle parlamenter demokrasi üzerinde yoğunlaştırarak yöntem sorununu gündeme getirmiş̧lerdir. Bu yöntem tartışmaları 12 Eylül askeri darbesinden sonra koalisyon hükümet sistemlerinin olduğu 1990'lı yıllarda da devam etmiştir. Bu süreç ekonomik, sosyal ve siyasi sonuçları olan 2001 krizi sonrasında gerçekleşen 3 Kasım 2002 seçimleri ile daha farklı bir boyuta getirmiştir. Ak Partinin iktidara gelmesi ile bu süreç, Türk siyasetinde uzun süredir tartışılan başkanlık sistemini daha güçlü bir şekilde gündeme taşımıştır. Türkiye, 2007 cumhurbaşkanlığı seçimi öncesinde ortaya çıkan "367 krizi” Parlamenter sistemin çözüm bulamadığ tıkanıklığa sahne olmuştur. Bu siyasal kriz 21 Ekim 2007 yılında yapılan anayasa referandumu (\%68,95 kabul oyu) ile "Cumhurbaşkanını Halkın seçmesi” yönünde yasalaşarak değiştirilmiştir. Nitekim 24 Ağustos 2014'te Cumhurbaşkanı, anayasal olarak ilk defa halk tarafından seçilmiştir. Böylelikle Türkiye'de, parlamenter sistemin ve istikrarsız koalisyonların neden olduğu çift başlı yönetim sistemi yerine fiili yarı başkanlık sistemine geçilmiştir (Duran ve Miş, 2016). Bu süreçte 1982 Anayasasından kaynaklanan Cumhurbaşkanlığının seçimi, tarafsızlığı, yetkileri ve hükümet ile olan ilişkileri siyasette tartışma konusu olmuştur. Ayrıca bu dönemde 2011 yılından beri devam eden Yeni Anayasa yapım çalışmaları, TBMM'de devam etse de anayasa komisyonunda meclis uzlaşısı sağlanamadığı için istenilen seviyeye gelememiştir. $\mathrm{Bu}$ tartışmalar, hükümet tarafından gündeme taşınsa da 2015 seçimlerinden sonra Ak Parti tek başına Anayasayı değiştirecek meclis çoğunluğu elinde bulunduramadığı için anayasa tartışmaları gündemden düşmüştür.

\section{Demokraside Yöntem Değişikliği, Cumhurbaşkanlığı Hükümet Sistemi}

Cumhurbaşkanlığı hükümet sistemi, 15 Temmuz 2016 Fetullahçı terör örgütü kalkıştığı darbe girişimi sonrası, oluşan siyasi birlikteliğin ürettiği ortak bir anlayış olarak ifade edilebilir. Türk siyasetinde 15 Temmuz sonrası sağlanan bu birliktelik, toplumsal niteliktedir. Bu birliktelik sosyal ve siyasal alanda ilk olarak 7 Ağustos 2016'da İstanbul Yenikapı "Demokrasi ve Şehitler Mitingi" nde ifade edilmiştir. İstanbul Yenikapı mitingine katılan liderler, 15 Temmuz darbe kalkışmasını hem iç hem de diş merkezli bir işgal girişimi olarak değerlendirmişlerdir. 15 Temmuz darbe girişiminde sonra yapılan siyasi değerlendirmeleri özellikle Ak Parti ve MHP'yi politik söylem açısından birbirine yakınlaştırırken; "Türkiye'nin Bekası" meselesi gündeme taşımıştır. 15 Temmuz sonrası ortaya çıan "Yenikapı Ruhu" siyasi yansımasını ilk olarak MHP'nin, terörle mücadelede konusunda hükümete verdiği destekle göstermiştir. MHP Genel Başkanı Devlet Bahçeli, hükümete verdiği bu desteği 11 Ekim 2016 TBMM'de MHP grup toplantısında bir adım daha ileri götürmüştür. Bahçeli, meclis grup toplantısında (Devlet Bahçeli Konuşmaları, 11 Ekim 2016)

\footnotetext{
“...Türkiye çok ciddi bir beka sorunuyla karşı karşıyadır. Milli birlik ve beraberliğin titizlikle korunması gereken bir dönemdeyiz. Kemikleşmiş önyargıları ve kısır çekişmeleri bir kenara bırakmalıyız. Siyasi gündemde kronik çekişme ve çatışma konusu olarak duran temel sorunları bu anlayışla ele almak, ülkemizin önünü açmak ve geleceğini planlamak durumundayız. Bunların en önemlilerinden birisi de hatırı sayılır zamandır ülkemizi meşgul eden yeni Anayasa kapsamında derinleşen hükümet sistemi tartışmalarıdır. Konu önemlidir; çünkü sistem tartışmaları siyaseti tıkarsa rejim krizine dönüşebilecektir..."
}

İfadelerini kullanarak Türk demokrasisinde, siyasal dönüşümün önünü açmıştır. Ayrıca Bahçeli, MHP'nin kırmızıçizgisi olan Anayasanın ilk dört maddesini değiştirmenden; yapılacak olan 
her türlü öneriye açık olduklarını belirtmiştir. Bu teklifi karşılıksız bırakmayan Ak Parti, MHP ile görüşmeleri başlatarak ortak bir komisyon kurmuştur. Türkiye'de siyasal demokrasinin dönüşümü için yönetimden ziyade bir yöntem değişikliğini öngören komisyon, Anayasa teklifi çalışmalarını tamamladı ve 10 Aralık 2016'hazırlanan taslağı TBMM'ye sunmuştur. Mecliste, önce anayasa komisyonunda görüşülen anayasa teklifi, 18 madde olarak meclis genel kurulunda geldi ve burada referandum oy sınırını (330) aşarak; Cumhurbaşkanının onayına sunulmuştur. Türk Demokrasisi açısından bir dönüm noktası olan yasa teklifini, Cumhurbaşkanının onaylaması üzerine Türkiye, referandum için 16 Nisan 2017'de sandık başına gitmiştir. 16 Nisan'da yapılan refarandumda seçmen, Anayasa teklifini $\% 51,41$ oy ile kabul etmiştir [Yüksek Seçim Kurulu (YSK), 2017]. Cumhurbaşkanlığı hükümet sistemine göre düzenlenen yeni yöntemde, cumhurbaşkanının görevleri, tarafsızlığı, yürütme ve yargı ile olan ilişkileri, parlamenter hükümet sisteminden farklı olarak düzenlenmiştir. Yeni Anayasa düzenlemesi ile yasama ve yürütme birbirinden ayrılarak; bakanların, yasama üyesi olmaması mecburiyeti kabul edilmiştir. Yeni düzenleme ile mecliste milletvekili sayıs1 550'den 600'e çıkarıldı, seçilme yaş1 ise 25'ten 18'e düşürüldü ve askerlik hizmetini yapmış olma koşulu kaldırılmıştır. Genel seçimlerin, beş yılda bir yapılmasına karar verilirken; bilgi edinme ve denetlemede değişikliğe gidilmiş̧tir (Resmi Gazete,11 Şubat 2017). Cumhurbaşkanlığı hükümet sistemi, 16 Nisan referandumu ile kabul edilirken; 24 Haziran 2018 Cumhurbaşkanı ve milletvekili seçimleri ile uygulamaya girmiş̧ir. Bu seçimlerde Ak Parti ve MHP'nin (Cumhur İttifakı) ortak adayı Erdoğan \%52,6 oy alarak yeni sistemin ilk Cumhurbaşkanı olmuştur (Sabah, 24 Haziran 2018). Cumhurbaşkanının yemin edip göreve başlamasının ardından, 703 Nolu Kanun Hükmünde Kararname (KHK) yayınlandı ve Başbakanlık ile birlikte birçok bakanlık ile kamu kurum ve kuruluşu kapatılmıştır. Bürokrasiyi yapılandıran, birçok teşkilat kanunu değiştirilerek; devlet teşkilatı 1 Nolu Cumhurbaşkanlığı Kararnamesi ile yeniden düzenlenmiştir. Türkiye'de, siyasal sistemde yapılan bu yöntem değişikliği, demokrasi açısından yeni bir süreçtir. Şüphesiz yeni yöntem değişikliği beraberinde bazı eleştirileri de getirmiştir. Bu eleştirilerin en başında bu değişikliğin bir siyasal rejim yani yönetim değişikliğine sebebiyet verme olasılığıdır. Özellikle MHP'nin 16 Nisan öncesi Anayasa çalışmalarında, Anayasa'nın ilk dört maddesini kırmızıçizgi olarak hassasiyetle bu yöntem değişikliğinin dışında bırakması ve yeni sistemde üniter devlet yapısını ve yönetim biçimini korumuştur. $\mathrm{Bu}$ nedenle yapılan tartışmaların yetersiz ve gereksiz olduğunu göstermiştir. Çünkü bu yöntem değişikliği, rejim değişikliğinden daha çok yönetimdeki belirsizliği, vesayetçi parlamenter sistemi, siyasi kurumsallaşmayı içeren bir düzenlemedir. Burada yapılmak istenen güçlü yönetim, güçlü meclis ile Türkiye'yi kırılgan ve ürkek demokrasiden, ileri demokrasiye siyasi kurumsallaşma ile geçirmek istediğidir. $\mathrm{Bu}$ anlamda yöntem değişikliğgi, klasik parlamenter sistemin dışında halkın seçtiği Cumhurbaşkanını, yönetimde sorumlu kılan, güçlü meclis yapısına sahip, üniter devlet esaslı demokratik bir hükümet sistemidir. Diğer yandan ise devlet, toplum ve ekonomi arasında olan etkileşime bakıldığında; yeni sistem devletin ekonomik piyasadaki rolü ve gücü üzerinde yeni bir dönüşümü ortaya koymuştur. Cumhurbaşkanlığı hükümet sisteminin, güçlü yapısı $(\% 50+1)$ istikrarlı bir ekonomiyi ortaya koyarken; parlamenter sisteme dayalı veya özellikle koalisyon hükümetlerinin ortaya koyduğu istikrarsız ekonomiyi ortadan kaldırmıştır.

\section{Sonuç, Tartışma ve Öneriler}

Bilinen tarifi ile demokrasi, insanı özgürleştirerek; ona kişiliğini, kimliğini ve toplumsal konumunu vermiştir. Günümüzdeki anlamını 18. Yüzyılda bulmuş olan demokrasi kavramı, bütün dünyayı, her açıdan etkilemiştir. Türk toplumu, Osmanlı Devletinden başlayarak; Cumhuriyet döneminde günümüze kadar demokrasiyi benimsemiş ve demokratikleşme yönünde hızlı ve kalıcı adımlar atmıştır. Bu demokratikleşme sürecinin en önemli faktörü, Türk siyasal hayatının vazgeçilmezi olan siyasal partilerdir. Batı'da modernleşme ile başlayan siyasal düşünce "halk egemenliği" esaslı demokrasiyi ve demokratik kültürü yaygınlaştırmıştır. Osmanlı Devleti, toplumsal yapıyı dinsel olarak ayırmadan halkı, yönetici sınıf ve reaya olmak üzere ikiye ayırması ile Batı ile arasında farklılık göstermiştir. Osmanlı Devleti'nde modernleşme hareketleri, Türk demokratikleşmesinin, söylem merkezini ve temel yapısını oluşturmaktadır. Bununla beraber, geleneksel yapıdan modern demokratik yapıya geçiş sürecini başlatmıştır. Osmanlı Devletinde Tanzimat Fermanı ilanı (1839), günümüz Türk Demokrasisinin belirleyici temeli olmakla beraber; siyasi katılımın ve siyasi kurumsal yapıların oluşmaya başladığı bir dönüm noktasıdır. Osmanlı 
Devleti'nde modernleşme hareketleri, Türk demokratikleşmesinin, söylem merkezini ve temel yapısını oluşturmaktadır. Bu demokratik dönüşüm, Osmanlı Döneminden başlayarak; Cumhuriyet Döneminde kurumsallaşmasını tamamlamıştır. Cumhuriyetin ilanı ile kuruluş felsefesinde yer alan modern, laik, demokratik ve hukuk devleti kavramları Türkiye Cumhuriyeti Devleti'nin var oluş ilkeleridir. Üniter devlet yapısına göre şekillenen devlet, 1923 yılından 1946 yılına kadar milli kimlik ve demokratik kurumsallaşmasını tek parti yönetimi ile tesis etmiştir. Daha sonra 1946 ile başlayan çok partili hayat ve demokratik siyaset, demokratik olmayan yöntemlerin başında gelen darbeler ile engellenmiştir. $\mathrm{Bu}$ engelleyici vesayetçi anlayış, hem iç hem de dış politik ve ekonomik odaklardan beslense de darbelerin siyasette bu kadar etkili olmasının en temel nedeni; demokratik siyasal sistemin gücü ve gelişimi ile ilgilidir. Türk demokrasisinde, siyaset sisteminin gelişim sürecine yönelik tartışmalar, Cumhuriyetin kuruluşundan beri devam etmiştir. Bu tartışmaların aktöreleri değişse de odak noktasını, yönetimden ziyade yöntem tartışmaları olmasıdır. Bu yöntem tartışmaları 1921 Anayasasının benimsediği kuvvetler birliği ilkesine karşı demokratik modeller üzerinde başlamıştır. Bu süreç tek parti yönetimine karşı ise parlamenter demokrasi üzerinde devam etmiştir. Bu tartı̧̧malar 1970'lerdeki koalisyon hükümetleri döneminde yönetim zorluğu açısından daha farklı bir noktaya gelmiştir. Türk siyasetinde sağ partiler (MSP ve MHP), bu tartışmaları özellikle parlamenter demokrasi üzerinde yoğunlaştırarak yöntem sorununu gündeme getirmişlerdir. Bu yöntem tartışmaları 12 Eylül askeri darbesinden sonra koalisyon hükümet sistemlerinin olduğu 1990'lı yıllarda da devam etmiştir. 3 Kasım 2002 sonrası AK Parti iktidarında, yeni anayasa tartışmaları devam etse de 2015 yılına kadar istenilen seviyeye ulaşamamıştır.

Türkiye'de demokratik siyaset, 15 Temmuz 2016 y1lında, yeni bir darbe girişimi ile karş1 karşıya kalmıştır. Bu darbe girişimine karşı Türk Milleti, demokrasiye olan inancı ve milli egemenliğe olan sadakati ile destansı bir direniş göstermiştir. Demokrasiye sahip çıkan bu milli direniş sayesinde darbe girişimi başarısızlıkla neticelenmiştir. Cumhurbaşkanlığ hükümet sistemi, 15 Temmuz 2016 Fetö hain darbe girişimi sonrası, oluşan siyasi birlikteliğin ürettiği ortak bir anlayış olarak ifade edilebilir. Türk siyasetinde 15 Temmuz sonrası sağlanan bu birliktelik, milliyetçi ve mukaddesatçı bir kimlik niteliğindedir. Bu değerler toplumsal ve siyasi alanda olarak ilk olarak 7 Ağustos 2016'da İstanbul Yenikapı "Demokrasi ve Şehitler Mitingi" nde ifade edildi. 15 Temmuz sonrası ortaya çıkan "Yenikap1 Ruhu" Türk demokrasisinde, siyasal dönüşümün önünü açmıştır. MHP Lideri Bahçeli meclis grup toplantısında anayasanın ilk dört maddesi değiştirilmeden devlet yönetiminde yöntem tartışmalarını başlatmıştır. Ak Parti ve MHP'nin, 18 maddelik anayasa düzenlemesi TBMM'den geçerek; 16 Nisan 2017'de halk oylaması ile kanunlaşmıştır.

Cumhurbaşkanlığı hükümet sistemine göre düzenlenen yeni yöntemde, Cumhurbaşkanının görevleri, tarafsızlığı, yürütme ve yarg1 ile olan ilişkileri, parlamenter hükümet sisteminden farklı olarak düzenlenmiştir. Türkiye'de, siyasal sistemde yapılan bu yöntem değişikliği, demokrasi açısından yeni bir süreçtir. Şüphesiz yeni yöntem değişikliği beraberinde bazı eleştirileri de getirmiştir. $\mathrm{Bu}$ eleştirilerin en başında bu değişikliğin bir siyasal rejim yani yönetim değişikliğine sebebiyet verme olasılığıdır. Fakat Anayasa'nın ilk dört maddesini kırmızıçizgi olarak hassasiyetle bu yöntem değişikliğinin dışında bırakması ve yeni sistemde üniter devlet yapısını koruması bu tartışmaları gereksiz ve yetersiz olduğunu göstermiştir. Çünkü bu yöntem değişikliği rejim değişikliğinden daha çok yönetimdeki belirsizliği, vesayetçi parlamenter sistemi, siyasi kurumsallaşmayı içeren bir düzenlemedir. Burada yapılmak istenen demokratik referanslı istikrarlı yönetim, güçlü meclis ile Türkiye'yi kırılgan ve ürkek demokrasiden, ileri demokrasiye siyasi kurumsallaşma ile geçirmek istediğidir. $\mathrm{Bu}$ anlamda yöntem değişikliği, klasik parlamenter sistemin dışında halkın seçtiği Cumhurbaşkanını yönetimde sorumlu kılan, güçlü meclis yapısına sahip, üniter devlet esaslı demokratik bir hükümet sistemidir.

Osmanlı modernleşme süreci ile başlayan Türk demokratikleşme hareketleri içerisinde Sait Halim Paşa ile başlayan (1908) başkanlık tartışmaları, siyasi olarak yüzyıllık bir geçmişe sahiptir. 20. Yüzyılın başlarından günümüze kadar devam eden sistem tartışmaları Erbakan, Demirel, Türkeş ve Özal gibi siyasi liderler tarafından dile getirilmiştir. $\mathrm{Bu}$ süreci Türk siyasi tarihi içerisinde demokratikleşme ile başlayan olgunlaşma süreci 18 Nisan 2017 Anayasa referandumu ile sonuçlanarak; siyasi, toplumsal ve hukuki olgunluğa erişmiştir. Bu olgunlaşma süreci Türkiye'de 
demokratikleşme hareketleri birçok kez sekteye uğramış bir süreçtir. Parlamenter sistem kaynaklı yaşanan ekonomik kriz ve askeri darbeler yanında istikrarsız yönetim ve sürekli seçim sarmalıda Türk demokrasisini olumsuz yönde etkilemiştir. Sonuç olarak Cumhurbaşkanlığ1 hükümet sistemi, parlamenter sistem içerisinde yer alan olumsuz durumları ortadan kaldırıcı veya dönüştürücü bir görev üstlenerek; istikrarlı bir yönetim anlayışını hedeflemiştir. Cumhurbaşkanlığı hükümet sistemi yönetim veya rejim merkezli olmayıp; yöntem merkezli bir dönüşümdür. Bunun içinde sistem üzerinde yapılan tartışma ve çalışmaların, doğru yönde belirlenmesine ve ilerlemesine katkı sağlayacak bu çalışma konu ile ilgili literatür kısıtlılığına zenginlik katacaktır. Ayrıca çalışma ilgili alanda yapılcak diğer çalışmalara demokrasi ve yöntem tartışmaları üzerinde kaynaklık ederek; özellikle demokrasi, Türk demokrasisi ve Türk Siyasi tarihinin yöntem odaklı bir yansıması olarak katkı sağlayacaktır.

\section{Kaynaklar}

Akyılmaz, G. (1999). Osmanlı Devleti'nde reaya kavramı ve devlet-reaya ilişkileri. Osmanlı, 4, ss. 40-55, Ankara: Yeni Türkiye Yayınları.

Armaoğlu, F. (1987). 20. Yüzyll siyasi tarihi. 4.Baskı, Ankara: Türkiye İş Bankası Yayınları.

Borak, S. Kocatürk, U. (1989). Atatürk'ün söylev ve demeçleri. C.III, 4.Baskı, Ankara: TİTE.

Cem, İ. (1998). Türkiye’de geri kalmışlı̆̆ın tarihi. 13. Baskı, İstanbul: Can Yayınları.

Çaha, Ö. (1994). Osmanlıda sivil toplum. Ankara Üniversitesi Siyasal Bilgiler Fakültesi Dergisi, 49(34), 79-99.

Çak1, F. (2018). Türkiye'de "15 Temmuz'un toplumsal etkileri ve ona yol açan faktörler üzerine düşünceler. Sakarya Üniversitesi Sosyal Bilimler Enstitüsü Akademik Incelemeler Dergisi, Cilt:13, Say1:1.

Çavdar, T. (1996). Türkiye’nin demokrasi tarihi. Cilt II, Ankara: İmge Yayınları.

Bahçeli, D. (2016). TBMM Grup Toplantısında Yaptıkları Konuşma. (Erişim Tarihi: 10.11.2019). http://www.mhp.org.tr/htmldocs/genel_baskan/konusma/4136/index.html

DİE. (1998). Milletvekili genel seçimi sonuçları. Ankara: DİE Matbaası.

Duran, B. ve Miş, N., (2016). 1970'lerden İtibaren Türkiye'de siyasal sistemin dönüşümü tartı̧maları ve gerekçeleri, "The trans formation of Turkey's political system and the exe cutive presidency", Insight Turkey, 18(4), 11-29.

Dursunoğlu, C. (1946). Millî Mücadelede Erzurum.2. Bask1, Ankara: Kaynak Yayınları.

Dursun, D. (1999). Demokratikleşemeyen Türkiye. İstanbul: İşaret Yayınları.

Eroğlu, H. (1990). Türk inkılâp tarihi. Ankara: Savaş Yayınları.

Gülener, S. (2016). Başkanlık sistemlerinde denge ve denetleme, SETA Rapor, İstanbul

Güngör, E. (1993). Dünden, bugünden, tarih, kültür, milliyetçilik. 6.bask1. İstanbul: Ötüken Yayınevi

Hale, W. (1996). Türkiye'de ordu ve siyaset, (Çev. Ahmet Fethi), İstanbul: Hil Yayınları.

İnan, A. (2000). Medeni bilgiler ve Mustafa Kemal Atatürk'ün el yazıları. Ankara: Atatürk Araştırma Merkezi Yayınları.

Kalaycıŏlu, E. ve Sarıbay A. Y. (1986). Tanzimat: modernleşme arayışı ve siyasal değişme. Türkiye'de siyaset: süreklilik ve değişim, 31 . 
Kalaycıŏlu, E. (1989). Demokratik konsolidasyon ve Türk siyasi hayatı. Bülten, Temmuz-Ekim, TDV Yayınları.

Karakurt, E. (2006).”Kentsel mekânı düzenleme önerileri: modern kent planlama anlayışı ve post modern kent planlama anlayışı" Erciyes Üniversitesi İktisadi ve Ídari Bilimler Fakültesi Dergisi, S.3.

Karpat, K. (2012). Türk demokrasi tarihi. İstanbul: Timaş.

Koç, T. Y. (2011). 12 eylülden 12 hazirana siyasi partiler. SETA sayı: 41 Erişim Tarihi 16.08.2019 http://file.setav.org/Files/Pdf/12-eylulden-12-hazirana-siyasal-partiler-ak-parti.pdf

Kürkçüoğlu, Ö. (1979) “Türk demokrasisinin kuruluş ve işleyişinde dış etkenler” AÜSBF Dergisi Cilt:3, Ankara: Sevinç Matbaası.

Mardin, Ş. (1994). Türk modernleşmesi. 3. Baskı, İstanbul: İletişim Yayınları

Mardin, Ş. (2003). Türkiye'de toplum ve siyaset. İstanbul: İletişim Yayıncılık.

Marshall, G. (1999). Sosyoloji sözlüğü. Ankara: Bilim Sanat Yayınları.

Özdemir, G. (2009) "Batı'da ve Türklerde egemenlik kavramı” Dumlupınar Üniversitesi Sosyal Bilimler Dergisi, S. 23, Kütahya.

Öztekin, A. (1993). Siyaset bilimine giriş. Malatya: Yeni Malatya Gazetesi Basım1.

Resmi Gazete (2017).6771 sayılı Türkiye Cumhuriyeti Anayasasında değişiklik yapılmasına dair kanun RG: 11Şubat 2017, 29976 https://www.resmigazete.gov.tr/eskiler/2017/02/201702111.htm (Erişim Tarihi: 30.11 .2019$)$

Sabah Gazetesi (2018). 24 Haziran seçim sonuçları. (Erişim Tarihi: 10.10.2018), https://www.sabah.com.tr/secim/24-haziran-2018-secim-sonuclari

Sarıbay, E. K. (1986). Tanzimat: modernleşme arayışı ve siyasal değişme Türk siyasal hayatının gelişimi,. İstanbul: Beta Yayınılık.

Sarınay, Y. (1994). Türk Milliyetçiliğinin tarihi gelişsimi ve Türk Ocakları. İstanbul: Ötüken Neşriyat.

Şıvgın, H. (1998. İslam ve demokrasi paneli tartışması İslam ve demokrasi. Ankara: TDV Yayınları

Sartori, G. (1996). Demokrasi teorisine geri önüş. (Çev., T. Karamustafaoğlu M. Turhan.). Ankara: Yetkin Yayınları.

Toker, M. (1991). Demokrasimizin İsmet paşalı yılları 1944-1973; Yarı silahlı yarı külahlı bir ara rejim 1960-1961. 2. Bask1, Ankara: Bilgi Yayınevi.

Tuncay, M. (1992).Türkiye Cumhuriyeti'nde tek parti yönetiminin kurulması 1921-1923, 3.Bask1, İstanbul: Cem Yayınevi.

Türkkan, H. (2018) "Osmanlı devleti'nde demokratikleşme ve Kanun-i Esasi'nin demokratik hürriyeti" Uluslararası Tarih Araştırmaları Dergisi, 376.

UBICINI M.A. (Tarihsiz). Türkiye mektupları, Çev. Cemal Karaağaçlı, c. 2, Tercüman 1001 Temel Eser

Ünal, A. A.(1997).Türkiye'de ordu, bürokrasi ve demokrasi. Türk Yurdu, sayı: 122, Ekim s.37.

Ünal, O. (1994). Türkiye'de demokrasinin doğuşu. İstanbul: Milliyet Yayınları.

Yüksek Seçim Kurulu Halkoylaması Sonuçları için bakınız http://www.ysk.gov.tr/tr/16-nisan-2017 anayasa-degisikligi-halkoylamasi/5002 (Erişim Tarihi: 25.11.2019) 


\section{Extended Abstract}

\section{Introduction}

Many definitions of the concept of democracy have been made from the period in which it emerged until today. These debates continue to point to what is the true definition of democracy. The reason for this confusion of meaning can be explained by the political, social and economic differences of each society. Theoretically, democracy, as it is today, emerged in the $18^{\text {th }}$ century and affected the whole world. The concept of democracy, which is based on the development of modernism, is an idea based on the individual and defines sovereignty according to the principle of equal citizenship. Ottoman Empire in terms of its relationship with the West in general, in $19^{\text {th }}$ century, he carefully followed the modernization efforts in Europe. However, the Ottoman modernization process does not show similar characteristics to Western modernization. This is because the processes of innovation in the West are formed by social movements outside the state. These social arrangements made him feel politically as well as socially and economically. Political thought that began with modernization in the West has spread democracy and democratic culture based on "popular sovereignty". The Ottoman Empire took its management concept from the Turkish culture and values. Therefore, the relationship between the state and society is a balanced limitation power between the state and society, rather than a "contract" or "compromise". Modernization movements in the Ottoman Empire constitute the central and basic structure of Turkish democratization. However, it initiated the transition from the traditional structure to the modern democratic structure. The proclamation of the Reformation edict (1839) in the Ottoman Empire is the defining foundation of today's Turkish democracy, but it is a turning point where political participation and political institutional structures began to form. The period we will examine now has been strengthened by the proclamation of the Republic (1923) in terms of the administration as well as the continuity of the method in terms of Turkish democracy. The process that started with the Turkish "liberation struggle" is the period after Lausanne, when a new state was admitted to the world with a new management approach with the proclamation of the Republic in 1923. The modern, secular, democratic and legal state concepts in the establishment philosophy of the Republic are the principles of existence of the Republic of Turkey. The state, shaped according to the unitary state structure, tried to establish national identity and democratic institutionalization from 1923 to 1946. In 1945, Turkey embarked on a dynamic process of political transformation that depended on both foreign and domestic developments. In the outside after World War II, "Western democracy " triumphed over dictatorships and one-party administrations. On the other hand, internal public opposition to the CHP has become widespread throughout the country. Since then, Turkey, aiming to strengthen its democracy in terms of continuity and permanence, has continued its path with the parliamentary system. Multi-party life and democratic politics, which began in 1946, were hampered by the early coups of undemocratic methods. The main reason why coups are so effective in politics is related to the strength and development of the Democratic political system, even though this inhibitory guardianship is fueled by both domestic and foreign political and economic focuses. In Turkish democracy, discussions about the development process of the political system have continued since the foundation of the Republic. These discussions focused particularly on parliamentary democracy and raised the question of methods in the system.

\section{Method}

This study will first focus on the concept of modern democracy and democratization movements in Turkish political history. Second, in the study, the Declaration of the Republic between 1920-1945 and the institutionalization process of democracy will be examined. Thirdly, the study will evaluate the transition to multiparty democratic life in Turkey and the general situation of the parliamentary system (1946-2017). Fourth, discussions on methods in democracy and the presidential system of government will be discussed in the study. The focus of the study as a qualitative research is democracy and the Turkish democratization process. In the light of the information that has emerged 
as a result, the contribution of the presidential system of government to the development of Turkish democracy in the context of Turkish democratization will be evaluated.

\section{Result, Discussion and Conclusion}

The political transformation of the democratic system in Turkey has come to the present day, starting from Reformation. Following the April 16, 2017 constitutional referendum on the method of governance, Turkey has moved to a "presidential system of government"and aimed to strengthen its democracy in all aspects. The strong administration that is wanted here is to move Turkey from a fragile and timid democracy to an advanced democracy through political institutionalization with a strong parliament. In this sense, the change of method is a democratic system of government based on a unitary state with a strong parliamentary structure, which makes the president elected by the people responsible for the administration, apart from the classical parliamentary system. While the strong structure $(50 \%+1)$ of the presidential system of government produced a stable economy, it was intended to eliminate the unstable economy based on the parliamentary system or especially the coalition governments. As a result, the presidential system of government has taken on a task of eliminating or transforming the negative situations within the parliamentary system and aimed at a stable understanding of governance.

The presidential system of government has aimed at a stable understanding of governance, taking on a task of eliminating or transforming the negative situations within the parliamentary system. The presidential system of government is not Administration or regime-centric, but a methodcentric transformation. For this reason, this study will contribute to the determination and progress of the discussions and studies on the system in the right direction and will add richness to the limitations of the literature on the subject. In addition, the study will contribute to other studies in the field of democracy and methods as a method-oriented reflection of democracy, Turkish democracy and Turkish political history. 